\title{
JESYA
}

JURNAL EKONOMI \& EKONOMI SYARIAH

Jurnal Ekonomi \& Ekonomi Syariah Vol 5 No 1, Januari 2022

E-ISSN : 2599-3410 | P-ISSN : 2614-3259

DOI : https://doi.org/10.36778/jesya.v5i1.681

\section{Manajemen Pendidikan Karakter Melalui Keterampilan Berbicara terhadap Peserta didik MDTA Muhammadiyah Pijorkoling}

\author{
Nikmah Sari Hasibuan \\ Universitas Muhammadiyah Tapanuli Selatan \\ nikmah.sari@um-tapsel.ac.id \\ Idawati \\ Universitas Muhammadiyah Tapanuli Selatan \\ Eli Marlina Harahap \\ Universitas Muhammadiyah Tapanuli Selatan \\ Happy Sri Rezeki Purba \\ Universitas Muhammadiyah Tapanuli Selatan \\ Nur Afifah \\ Universitas Muhammadiyah Tapanuli Selatan
}

\begin{abstract}
Abstrak Pendidikan Karakter sudah mulai hilang dari diri peserta didik. Maka penelitian ini bertujuan untuk mengimplementasikan pendidikan karakter melalui keterampilan berbicara. Keterampilan berbicara dibuat dalam dua metode, yaitu metode bercerita dan berpidato. Teknik pengumpulan data dilakukan secara observasi, wawancara, beserta dokumentasi yang merupakan penelitian kualitatif dengan pendekatan fenomelogi. Selanjutnya, analisis data dilakukan dengan triangulasi. Dari Sembilan pendidikan karakter yang dirumuskan Indonesia Heritage Foundation (IHF) ada tujuh pendidikan karakter yang ditemukan pada peserta didik di MDTA Muhammadiyah Pijorkoling. Pendidikan karakter itu terdiri dari kejujuran, cinta kepada Allah, kemandirian, kreatif, rendah hati, percaya diri, hormat, dan santun. adapun faktor yang menghambat implementasi pendidikan karakter melalui keterampilan berbicara yaitu dari lingkungan eksternal seperti tidak adanya dukungan keluarga, pandemi covid-19 yang membuat tatap muka berkurang, tontontan televise dan media sosial yang tak dipantau. Kemudian faktor-faktor yang mendukung implementasi yaitu dukungan dari sekolah dan pihak eksternal sekolah yang harus bekerja sama. Dengan demikian, implementasi pendidikan karakter melalui keterampilan berbicara perlu dilakukan secara signifikan dan berulang-ulang. Secara otomatis, pendidikan karakter tersebut akan teritegrasi pada peserta didik sebagai cikalbakal masa depan anak bangsa.
\end{abstract}

Kata Kunci pendidikan karakter, keterampilan berbicara 


\section{JESYN}

JURNAL EKONOMI \& EKONOMI SYARIAY

Jurnal Ekonomi \& Ekonomi Syariah Vol 5 No 1, Januari 2022

E-ISSN : 2599-3410 | P-ISSN : 2614-3259

DOI : https://doi.org/10.36778/jesya.v5i1.681

\section{PENDAHULUAN}

Dewasa ini fenomena maraknya pergaulan bebas, bolos saat proses belajar mengajar berlangsung, tidak punya semangat belajar, melawan kepada guru, tidak sopan dan tidak hormat saat berbicara kepada guru atau teman sejawatnya. Selain hal itu, turunnya pendidikan karakter peserta didik disebabkan juga oleh tontonan televisi yang belum sesuai pada umur mereka beserta media sosial yang sudah akrab bahkan menjadi teman keseharian mereka di rumah dan masih banyak lagi prilaku negatif peserta didik yang mengindikasikan telah menurunnya karakter peserta didik. Hal tersebut sangat memprihatinkan sehingga pemerintah mencanangkan pengembangan karakter melalui dunia pendidikan. Selanjutnya, Indonesia Heritage Foundation (IHF) sudah merumuskan ada 9 nilai pendidikan karakter yang perlu ditanamkan kepada peserta didik, yaitu (1) Cinta Allah dengan segenap ciptaan-Nya, (2) Kemandirian, tanggung jawab, (3) Kejujuran, bijaksanan, (4) Hormat, santun, (5) Dermawan, suka menolong, gotong royong, (6) Percaya diri, kreatif, bekerja keras, (7) Kepemimpinan, keadilan, (8) Baik hati, rendah hati, (9) Toleransi, kedamaian.

Pernyataan ini juga diperkuat dengan Permendiknas No. 23 tahun (2006) menyatakan bahwa ada ada empat nilai karakter utama yang menjadi pedoman penerapan kepribadian siswa di sekolah, yaitu kejujuran (hati), kecerdasan (pikiran), kekuatan (olahraga) dan kebajikan (hati). Dengan demikian, ada banyak pendidikan karakter yang dapat dikembangkan dan diinmpementasikan ke dalam pembelajaran di sekolah. Mengimpelemntasikan semua nilai-nilai pendidikan karakter ini adalah tugas yang sangat sulit. Oleh karena itu, perlu dipilih beberapa nilai prioritas untuk ditanamkan pada peserta didik.

Pendidikan karakter akan berhasil jika dilakukan secara simultan mulai dari diri sendiri, keluarga, sekolah, masyarakat, bangsa dan semesta. Pengimplementaaian pendidikan karakter ini dapat dilakukan melalui pembinaan keterampilan berbicara kepada peserta didik. Pemilihan keterampilan berbicara untuk pengimplementasian pendidikankarakter dianggap relevan karena tujuan dari berbicara itu adalah berkomunikasi. Dengan demekian, keterampilan berbicara yang baik akan dapat menghasilkan komunikasi yang baik dan mengandung pendidikan karakter.

Maraknya masalah pendidikan karakter yang belum bisa dituntaskan beserta kurangnnya keterampilan berbicara peserta didik menjadi masalah utamabagi setiap pendidik. Bahkan fenomena tersebut juga megundang perhatian banyak pihak diantaranya kalangan akademisi. Sebagai wujud sumbangsih dari penyelesaian permasalah itu beberapa peneliti menyumbang hasil penelitiannya, seperti Hidayah (2015) yang meneliti nilai-nilai karakter dalam pembelajaran bahasa Indonesia. Kemudian, SP (2016) yang meneliti penanaman nilai-nilai karakter melalui implementasi pendidikan karakter sekolah dasar, selanjutnya Hasibuan (2019 (2020)) yang meneliti tentang analisis nilai moral pada cerita rakyat Sampuraga pada masyarakat Mandailing Natal, dan Febrianshari (2018) yang meneliti nilai-nilai pendidikan karakter dalam pembuatan dompet punch zaman Now.

Hal yang sama dilakukan Ningsih (2014) dalam penelitiannya tentang peningkatan keterampilan berbicara melalui metode bercerita siswa Kelas III SD Negeri 1 Beringin Jaya Kecamatan Bumi Raya Kabupaten Morowali, selanjutnya Hidayati (2018) yang meneliti tentang peningkatan keterampilan berbicara melalui pendekatan komunikatif kelas V SD Padurenan II di bekasi. Dan yang terakhir Afdalifah, dkk (2020) yang mengkaji tentang peningkatan keterampilan berbicara dengan metode bercerita pada anak usia dini di sekolah alam excellentia Pamekasan. 


\section{JESYA}

JURNAL EKONOMI \& EKONOMI SYARIAH

Jurnal Ekonomi \& Ekonomi Syariah Vol 5 No 1, Januari 2022

E-ISSN : 2599-3410 | P-ISSN : 2614-3259

DOI : https://doi.org/10.36778/jesya.v5i1.681

Hasil penelitian-penelitian di atas akan sangat bermanfaat bagi seluruh komponen untuk menentukan sikap dan langkah dalam mengimplementasikan pendidikan karakter pada peserta didik.

Minimnya pendidikan karakter peserta didik ini terjadi juga di MDTA Muhammadiyah Pijorkoling. Berdasarkan hasil observasi dan wawancara dengan guru MDTA Muhammadiyah bahwa peserta didik masih kurang dalam pengimplementasian pendidikan karakter. Dalam hal tersebut peneliti tertarik melaksanakan penelitian dengan rumusan masalah "Bagaimana Pengimplemntasian pendidikan karakter melalui keterampilan berbicara pada peserta didik di Madrasah Diniyah Takmiliyah Awaliyah (MDTA) Muhammadiyah Pijorkoling?"

\section{KAJIAN TEORITIS}

Pendidikan karakter merupakan kata yang sangat umum dalam dunia pendidikan. Secara umum, pendidikan dapat diartikan sebagai sebuah usaha yang dilakukan untuk mengubah perilaku dan sikap seseorang untuk menjadi lebih baik. pendidikan adalah suatu upaya yang dilakukan agar manusia hidup sebagaimana layaknya manusia (Wahyudin, 2009). Selanjutnya winkel (2021) menyatakan bahwa pendidikan merupakan usaha yang dilakukannoleh orang dewasa guna memberi bantuan kepada orang-orang yang belum dewasa untuk mampu bertindak sebagai seorang dewasa. Berdasarkan penjelasan tersebut dapat disimpulkan bahwa tujuan utama dari pendidikan adalah mendewasakan orang yang belum dewasa dengan membentuk kepridadian dan karakter yang baik.

"Character" adalah kata yang berasal dari bahasa yunani, yatu charassein yang artinya menggambar atau melukis. Dalam Alwi Hasan, dkk. (2007) karakter diartikan sebagai akhlak, sifat, perilaku yang menjadi ciri khas seseorang. Selanjutnya Musfiroh (2008) mendefenisikah bahwa karakter berfokus pada serangkaian sikap, perilaku, keterampilan, dan motivasi. Sedangkan Rahayu (2016) menjelaskan secara singkat bahwa karakter adalah kepridadian yang dimiliki seseorang. Karakter seseorang dipengaruhi oleh faktor internal (bawaan) dan eksternal (lingkungan).

Menurut Kemdiknas tahun 2010, pendidikan karakter adalah pendidikan yang menanmkan nilai-nilai karakter atau nilai-nilai yang luhur kepada seluruh peserta didik sehingga peserta didik mempunyai dan mampu menerapkan nilai-nilai tersebut baik sebagai individu, masyarakat maupun warga Negara. Pendidikan karakter adalah suatu usaha yang dilakukan dalam pendidikan untuk menanamkan nilai-nilai karakter kepada seluruh warga sekolah yang meliputi pengetahuan, kesadaran, dan kemauan untuk melakukan tindakan sebagai wujud nilai karakter tersebut baik kepada Tuhan YME, diri sendiri, sesama lingkungan, dan lain sebagainya (Samani \& Hariyanto, 2013). Berhubungan dengan nilai-nilai karakter tersebut, Megawangi (Kesuma, 2012) mengemukakan ada sembilan karakter positif yang akan menjadi target dalam program pembelajaran yang disesuaikan dengan tahap perkembangan anak. Sembilan nilai karakter ini sesuai dengan nilai yang tercantum dalam Indonesia Heritage Foundation (IHF), yaitu: Cinta Allah, dengan segenap ciptaan-Nya (love Allah, trust, reverence, loyalty); Kemandirian, tanggung jawab (responsibility, excellence, self reliance, discipline, orderliness); Kejujuran, bijaksanan (trustworthiness, reliability, honesty); Hormat, santun (respect, courtesy, obedience); Dermawan, suka menolong, gotong royong (love, compassion, caring, emphaty, generousity, moderation, cooperation); Percaya diri, kreatif, 


\section{JESYN}

JURNAL EKONOMI \& EKONOMI SYARIAH

Jurnal Ekonomi \& Ekonomi Syariah Vol 5 No 1, Januari 2022

E-ISSN : 2599-3410 | P-ISSN : 2614-3259

DOI : https://doi.org/10.36778/jesya.v5i1.681

bekerja keras (confidence, assertiveness, creativity, resourcefulness, courage, determination and enthusiasim); Kepemimpinan, keadilan (justice, fairness, mercy, leadership); Baik hati, rendah hati (kindness, friendliness, humility, modesty); Toleransi, kedamaian (tolerance, flexibility, peacefulness, unity).

Keterampilan berbicara adalah salah satu jenis keterampilan berbahasa yang harus dikuasai. Keterampilana berbicara merupakan suatu kemampuan seseorang dalam menyampaikan dan menuangkan pikirannya melalui bahasa lisan sehingga bisa dipahami orang lain dengan baik. Sebagaimana yang dikatakan oleh Rivers (dalam Purwadi, dkk., 2021) bahwa keterampilan berbicara adalah kemampuan seseorang dalam mengggunakan bahasa secara lisan dan alamiah dengan memanfaatkan segala sesuatu yang berhubungan dengan topic pembicaraan secara nyata. Di sisi lain, Tomskin \& Hoskisson (dalam Rofi'udin \& Zuchdi, 2001) menjelaskan bahwa untuk melatih keterampilan berbicara seseorang dapat dilakukan melalui beberapa cara, salah satunya adalah berbicara informatik seperti bercerita dan berpidato.

Bercerita merupakan suatu kegiatan yang dilakukan seseorang untuk menjelaskan, mengungkapkan, dan mengisahkan tentang suatu kejadian baik itu kebahagiaan atau kesakitan dalam dunia nyata maupun imajinasi yang dirasakan oleh seseorang atau orang lain. Bercerita merupakan salah satu jenis keterampilan berbicara yang dilakukan untuk memberitahukan kemampuan pragmatis seseorang (Nurgiyantoro, 2021). Di sisi lain, Tarigan (dalam Purwadi, dkk., 2021) mengungkapkan bahwa berpidato merupakan suatu kegiatan yang dilakukan dengan menggunakan bahasa lisan yang disampaikan secara formal untuk memberikan informasi, pendapat, dan stimulus sesuai dengan topik yang ditetapkan dan disusun secara secara sistematis untuk memberikan dan mendapatkan respon terkait opini atau pendapat-pendapat orang lain. Selanjutnya Apriani (2013) memberikan penjelasan bahwa bercerita dan berpidato merupakan jenis dari keterampilan berbicara untuk memberikan informasi kepada orang lain terkait kejelasan makna. Dengan demikian dapat disimpulkan bahwa keterampilan berbicara merupakan suatu kemampuan yang dimiliki seseorang untuk mengungkapkan apa yang ada di dalam pikiran. Selain itu, keterampilan berbicara merupakan suatu keterampilan yang dapat dilatih dengan berbagai cara, termasuk bercerita dan berpidato.

\section{METODE PENELITIAN}

Penelitian ini merupakan penelitian kualitatif dengan pendekatan fenomenologi, yang bermaksud memahami fenomena tentang apa yang dialami oleh subjek penelitian misalnya sikap, persepsi, motivasi, tindakan secara gabungan dan dengan cara deskripsi dalam bentuk kata-kata dan bahasa, pada suatu konteks khusus dengan memanfaatkan keterampilan berbicara metode cerita dan pidato. Selanjutnya, dalam memperkuat penelitian ini peneliti melakukan wawancara dengan beberapa informan yang mengetahui, memahami dan mengalami permasalahan yang diajukan dalam penelitian. Subjek penelitian adalah kepala sekolah MDTA Muhammadiyah Pijorkolong, guru, dan peserta didik. Pengumpulan data dilakukan dengan teknik observasi, wawancara, dan dokumentasi. Analisis data dilakukan dengan menganalisis hasil penelitian berdasarkan reduksi data, penyajian data, dan penarikan kesimpulan.

\section{HASIL DAN PEMBAHASAN}

\section{A. Hasil Penelitian}




\section{JESYA}

JURNAL EKONOMI \& EKONOMI SYARIAH

Jurnal Ekonomi \& Ekonomi Syariah Vol 5 No 1, Januari 2022

E-ISSN : 2599-3410 | P-ISSN : 2614-3259

DOI : https://doi.org/10.36778/jesya.v5i1.681

\section{1) Implementasi Pendidikan Karakter melalui Keterampilan Berbicara Metode Cerita di MDTA Muhammadiyah Pijorkoling}

Pada penelitian ini peneliti melakukan teknik wawancara dan dokumentasi untuk mendapatkan informasi. Ibu Nur Ainun Harahap selaku salah satu guru di MDTA Muhammadiyah Pijorkoling mengungkapkan bahwa "Pendidikan karakter melalui keterampilan berbicara sangat diperlukan strategi dalam mengintegrasikan pendidikan karakter secara bertahap". Pendapat tersebut didukung oleh bapak Parsaulian yang menyatakan bahwa "Pendidikan karakter pada keterampilan berbicara seperti bercerita dan berpidato membutuhkan waktu yang cukup lama". Sejalan dengan pendapat tersebut MS (peserta didik) mengungkapkan bahwa "Melalui bercerita seperti memperkenalkan diri, perjalanan, dan menceritakan hal-hal yang disukai dapat mengasah komunikasi yang mengandung nilai-nilai karakter, seperti nilai kejujuran, cinta kepada Allah, kemandirian, dan kreatif".

Berdasarkan hal tersebut, maka dapat disimpulkan bahwa guru dan peserta didik di MDTA Muhammadiyah Pijorkoling dalam mengimplementasikan pendidikan karakter melalui keterampilan berbicara dapat membantu peserta didik dalam menerapkan nilai-nilai pendidikan karakter terhadap peserta didik itu sendiri.

2) Implementasi Pendidikan Karakter melalui Keterampilan Berbicara Metode Pidato di MDTA Muhammadiyah Pijorkoling

Implementasi pendidikan karakter melalui keterampilan berbicara dengan menggunakan metode berpidato dapat mengembangkan pengetahuan dan bakat anak. Hal ini sejalan dengan pendapat Ibu Nurul Midayati, SHi. dan NS (peserta didik). Ibu Nurul Midayati, SHi. selaku wali kelas 3 MDTA Muhammadiyah Pijorkoling menyatakan bahwa "untuk membina karakter peserta didik perlu diikuti setiap perkembangan peserta didik sehingga selaku guru dapat memantau terhadap pendidikan karakter yang harus dikuasai peserta didik beserta pendidikan karakter yang harus diintegrasikan selanjutnya". Dalam keterampilan berbicara metode berpidato peserta didik dapat menguasai pendidikan karakter seperti rendah hati, percaya diri, hormat, dan santun.

Selanjutnya NS (peserta didik) mengungkapkan bahwa "perlunya memberikan hadiah bagi siapa saja yang dapat berpidato dengan baik". Hal demikian memperkuat adanya kerja keras dari peserta didik dalam belajar berpidato. Berpidato menjadi salah satu metode yang dapat dilakukan untuk mengintegrasikan nilai-nilai pendidikan karakter terhadap keterampilan berbicara peserta didik. Berdasarkan pemaparan dari hasil wawancara dan dokumentasi tersebut, maka dapat disimpulkan bahwa bentuk implementasi pendidikan karakter melalui berpidato terdiri dari rendah hati, percaya diri, hormat dan santun, serta kerja keras.

Untuk memperkuat pernyataan di atas, berikut dipaparkan jadwal keterampilan berbicara yang dilaksanakan di MDTA Muhammadiyah Pijorkoling.

Tabel 1. Daftar jadwal kegiatan keterampilan berbicara di MDTA Pijorkoling

\begin{tabular}{|l|l|l|l|}
\hline No & Keterampilan berbicara & Jenis kegiatan & Hari pelaksanaan \\
\hline 1 & Metode Bercerita & $\begin{array}{l}\text { 1. Memperkenalkan diri } \\
\text { 2. Menceritakan perjalanan } \\
\text { 3. Hal-hal yang disukai }\end{array}$ & Setiap hari Sabtu \\
\hline 2 & Metode Berpidato & $\begin{array}{l}\text { 1. Tema Ahlak } \\
\text { 2. Tema Ibu }\end{array}$ & Setiap Hari Jum'at \\
\hline
\end{tabular}




\section{JESYA}

JURNAL EKONOMI \& EKONOMI SYARIAH

Jurnal Ekonomi \& Ekonomi Syariah Vol 5 No 1, Januari 2022

E-ISSN : 2599-3410 | P-ISSN : 2614-3259

DOI : https://doi.org/10.36778/jesya.v5i1.681

3. Tema Mencintai Alam

Sumber data Kepala Sekolah MDTA Muhammadiyah Pijorkoling

3) Faktor-faktor Yang Menghambat Implementasi Pendidikan Karakter Melalui Keterampilan Berbicara

Pada proses pelaksanaan keterampilan berbicara guru mempunyai kendala, salah satunya saat guru sudah mulai melatih keterampilan berbicara peserta didik namun ada salah satu yang menolak untuk belajar. Ibu Nurul Hidayati, SHi.sebagai salah satu guru MDTA Muhammadiyah Pijorkoling mengungkapkan "anak zaman sekarang memang sangat susah untuk dibina karena itu butuh kesabaran eksrra untuk menumbahkan karakter mereka, saya rasa sebagain penyebabnya selain pandemi covid-19 yang kurang dalam tatap muka, cuaca yang tak menentu, hambatan lainnya adalah tidak adanya dukungan orang tua dalam hal membina pendidikan karakter anak.

Sejalan dengan pendapat tersebut, Bapak Parsaulian selaku kepala sekolah juga menyampaikan "Pendidikan karakter harus dibina dengan semua kalangan masayarkat, baik individu, keluarga, guru di sekolah atau di kalangan masyarakat itu sendiri, dan jika hanya salah satu yang fokus untuk mengintegrasikan pendidikan karakter itu maka tidak menutup kemungiinan akan lama dalam penananam pendidikan karakter peserta didik"

Selanjutnya, dari hasil observasi dengan peserta didik, mereka lebih dominan menyukai tontonan televisi dan media sosial daripada belajar, lebih banyak mengetahui kata-kata yang tak bermanfaat daripada kata-kata yang memotivasi mereka sendiri dalam belajar. Hal yang demikian yang menjadi salah satu pemicu susahnya untuk mengimtegrasikan pendidikan karakter dalam diri peserta didik.

Berdasarkan hal tersebut, melalui wawancara dan observasi dapat disimpulkan bahwa hambatan dalam mengimplementasikan pendidikan karakter peserta didik terdiri dari tidak adanya dukunga keluarga, pandemi covid-19 yang membuat tatap muka berkurang, tontontan televise dan media sosial yang tak dipantau.

\section{4) Faktor-faktor Yang Mendukung Implementasi Pendidikan Karakter Melalui Keterampilan Berbicara}

Selaku kepala sekolah, Bapak Parsaulian mengungkapkan bahwa "hal yang mendukung implementasi pendidikan karakter itu sendiri adalah (1) kebijakan dari sekolah yang setiap saat siap dalam membina, (2) memberikan seminar tentang pendidikan karakter terhadap seluruh guru di MDTA Muhammadiyah Pijorkoling, (3) terbuka dan menyambut baik bagi akademisi atau pakar lainnya yang melaksanakan penelitian dan pengabdian untuk membantu dalam mengintegrasikan pendidikan karakter.

Hal tersebut juga didukung oleh Ketua Ranting Nusruddin Harahap yang menyatakan "sebagai aparat desa kami selalu bersedia dalam membantu apa saja yang dibutuhkan untuk membina akhlak anak-anak yang nantinya mereka akan menjadi penerus kita"

Berdasarkan pemaparan di atas dapat disimpulkan bahwa faktor pendukung implementasipendidikan karakter melalui keterampilan berbicara yaitu dukungan dari sekolah dan pihak eksternal sekolah yang harus sama-sama kerja sama.

\section{B. Pembahasan}




\section{JESYA}

JURNAL EKONOMI \& EKONOMI SYARIAH

Jurnal Ekonomi \& Ekonomi Syariah Vol 5 No 1, Januari 2022

E-ISSN : 2599-3410 | P-ISSN : 2614-3259

DOI : https://doi.org/10.36778/jesya.v5i1.681

\section{1) Implementasi Pendidikan Karakter melalui Keterampilan Berbicara Metode Cerita di MDTA Muhammadiyah Pijorkoling}

Melalui hasil wawancara dan observasi yang sudah dilakukan, terlihat jelas bahwa pengintegrasian karakter anak terhadap peserta didik diperlukan pendidikan. Hal tersebut, sejalan dengan pendapat Wahyudin (2009) yang menyatakan sebuah usaha dilakukan untuk mengubah perilaku dan sikap seseorang menjadi lebih baik agar manusia hidup sebagaimana layaknya manusia adalah melalui pendidikan. Hal ini juga diperkuat Kemdiknas (2010) menanamkan nilainilai karakter atau nilai-nilai yang luhur kepada seluruh peserta didik agar peserta didik mempunyai dan mampu menerapkan nilai-nilai tersebut baik sebagai individu, masyarakat maupun warga Negara.

Dari hasil observasi dan wawancara yang sudah dilakukan di MDTA Muhammadiyah Pijorkoling dapat disimpulkan dari sembilan nilai pendidikan karakter yang telah dirumuskan IHF (Indonesia Heritage Foundation) ada empat nilai karakter yang sudah terintegrasi dalam peserta didik melalui keterampilan berbicara metode cerita. Adapun nilai pendidikan karakter tersebut antara lain: nilai karakter kejujuran, cinta kepada Allah, kemandirian dan kreatif. Pengintegrasian tersebut tidak lepas dari kinerja guru, kepala sekolah dan pihak-pihak eskternal sekilah yang selalu mendukung dalam mengimpelemntasikan nilai pendidikan karakter tersebut.

Berdasarkan pemaparan di atas, dapat disimpulkan bahwa impelemtasi pendidikan karakter melalui keterampilan berbicara yang telah dilakukan merupakan salah satu cara dalam mengatasi prilaku negatif anak pada dewasa ini.

\section{2) Implementasi Pendidikan Karakter melalui Keterampilan Berbicara Metode Pidato di MDTA Muhammadiyah Pijorkoling}

Bertumpu pada pendapat Musfiroh (2008) yang mendefenisikah bahwa karakter berfokus pada serangkaian sikap, perilaku, keterampilan, dan motivasi. Maka dapat dilihat implementasi pendidikan karakter melalui keterampilan berbicara sanga erat sekali hubungannya. Hal yersebut dapat dilihat berdasarkan hasil observasi dan wawancara beserta dokumentasi yang sudah dilakukan di MDTA Muhammadiyah bahwa impelemtasi pendidikan karakter melalui keterampilan berbucara sangat mempengaruhi sikap dan prilakuk peserta didik. Hal ini juga diperkuat Rahayu (2016) yang mengungkapkan bahwa karakter adalah kepribadian yang dimiliki seseorang. Karakter seseorang dipengaruhi oleh faktor internal (bawaan) dan eksternal (lingkungan). Pada peserta didik MDTA Muhammadiyah diperlukan motivasi dari dalam dan luar peserta didik sendiri untuk dapat mengimpelemtasikan pendidikan karakter tersebut.

Selanjutnya, dari sembilan nilai-nilai pendidikan karakter yang sudah dirumuskan IHF (Indonesia Heritage Foundation) terdapat empat nilai pendidikan karakter yang sudah terintegrasi pada peserta didik MDTA Muhammadiyah Pijorkoling melalui keterampilan berbicara dengan menggunakan metode berpidato. Adapun niali pendidikan karakter tersebut terdiri dari: karakter percaya diri, rendah hati, hormat dan santun, kerja keras.

Berdasarkan pemaparan di atas, dapat disimpulkan bahwa implementasi pendidikan karkater melalui keterampilan berbicara metode berpidato mendapatkan hasil yang positif. Hal ini terlihat dengan adanya pendidikan karakter yang sudah terintegrasi pada peserta didik. Dengan demikian, implementasi pendidikan karakter melalui keterampilan berbicaradapat meningkatkan prestasi peserta didik. 


\section{JESYA}

JURNAL EKONOMI \& EKONOMI SYARIAH

Jurnal Ekonomi \& Ekonomi Syariah Vol 5 No 1, Januari 2022

E-ISSN : 2599-3410 | P-ISSN : 2614-3259

DOI : https://doi.org/10.36778/jesya.v5i1.681

\section{3) Faktor-faktor Yang Menghambat Implementasi Pendidikan Karakter Melalui Keterampilan Berbicara}

Dari hasil observasi dan wawancara yang sudah dilakukan di MDTA Muhammadiyah Pijorkoling terdapat hambatan pada implemtasi pendidikan karakter melalui keterampilan berbicara. Hambatan tersebut bersifat eksternal (dari luar diri) peserta didik. Salah satu contohnya karena situasi, cuaca dan kelarga. Hal tersebut didukung oleh pendapat Sardiman (2012) yang menyatakan bahwa karakter peserta didik merupakan hasil dari pembawaan dari lingkungan sosialnya. Lingkungan sosial ini sangat berpengaruh terhadap kemampuan dan karakter peserta didik.

Sejalan dengan hal tersebut, Firdaus (2012) juga mengungkapkan bahwa lingkungan keluarga merupakan lingkungan pendidikan yang utama dan utama bagi anak karena di sinilah mereka memperoleh pendidikan dan bimbingan pertama kali. Hal ini terlihat jelas bahwa setiap kemampuan dan karakter peserta didik harus ada campur tangan dari keluarga. Apabila keluarga dari peserta didik kurang memberikan motivasi maka peserta didik juga akan tertinggal dengan peserta didik yang mendapatkan motivasi dari keluarga.

Berdasarkan pemaparan di atas, dapat disimpulkan bahwa pendidikan karakter anak akan terhambat apabila tidak adanya dukungan dari pihak eksternal. Pihak eksternal yang paling dominan disini adalah keluarga peserta didik itu sendiri. Ada tiga aspek yang dapat mengahmbat pendidikan karakter peserta didik : (a) situasi ekonomi keluarga, (b) kedekatan orang tua dan anak, dan (c) lingkungan sosial keluarga

\section{4) Faktor-faktor Yang Mendukung Implementasi Pendidikan Karakter Melalui Keterampilan Berbicara}

Dalam pelaksanaan proses pembelajaran perlu dukungan dari beberapa kalangan untuk mengimplementasikan pendidikan karakter peserta didik. Dukungan tersebut sangat erat kaitannya dengan berhasil atau tidaknya seorang pendidik dalam membentuk karakter peserta didik tersebut. Pendapat ini diperkuat dengan apa yang disampaikan Rahayu (2018) yang menyatakan bahwa ada lima jenis bidang: 1) bidang masing-masing, 2) bidang sosial, 3) pelatihan dalam negeri, beserta 4) disiplin dalam bidang ilmu pengetahuan, 5) bidang pekerjaan.

Dari hasil obeservasi dan wawancara yang sudah dilakukan di MDTA Muhammadiyah Pijorkoling terdapat beberapa faktor yang sesuai dengan bidang dalam mengintegrasikan pendidikan karakter peserta didik. Hal yang dimaksud adalah, dukungan Kepala sekolah, masyarakat dan pihak terlibat lainnya dalam membentuk karakter masa depan anak bangasa.

Selanjutnya, Permendiknas No. 23 tahun (2006) menyatakan bahwa ada empat nilai karakter utama yang menjadi pedoman penerapan kepribadian siswa di sekolah, yaitu kejujuran (hati), kecerdasan (pikiran), kekuatan (olahraga) dan kebajikan (hati). Berdasarkan hasil pemaparan di atas, keempat hal tersebut akan terpenuhi apabila ada kerja sama yang baik antara pihak sekolah dengan pemangku kepentingan dalam proses belajar peserta didik.

\section{KESIMPULAN}

Berdasarkan latar belakang masalah, kajian pustaka serta hasil dan pembahasan di atas, maka dapat disimpulkan bahwa pendidikan karakter adalah pendidikan yang berusaha menanamkan dan mengembangkan karakter baik dalam diri peserta didik. Pendidikan karakter 


\section{JESYA}

JURNAL EKONOMI \& EKONOMI SYARIAH

Jurnal Ekonomi \& Ekonomi Syariah Vol 5 No 1, Januari 2022

E-ISSN : 2599-3410 | P-ISSN : 2614-3259

DOI : https://doi.org/10.36778/jesya.v5i1.681

dapat diimplementasikan kepada peserta didik melalui keterampilan berbicara. Jenis keterampilan berbicara yang digunakan untuk mengimplementasikan pendidikan karakter tersebut adalah melalui metode bercerita dan mentode berpidato. Dalam pengimplementasian pendidikan karakter melalui metode bercerita dan berpidato di MDTA Muhammadiyah Pijorkoling tersebut dilakukan setiap hari Jum'at dan Sabtu. Pengimplementasian nilai pendidikan karakter yang dilakukan didukung oleh pihak sekolah dengan sama-sama bekerja sama dalam mengimplementasikan pendidikan karakter tersebut melalui keterampilan bercerita dan berpidato.

Selanjutnya, melalui metode bercerita, nilai pendidikan karakter yang dapat diimplementasikan meliputi nilai kejujuran, cinta kepada Allah kemandirian, dan kreatif. Sedangkan melalui metode berpidato, hasil implementasi nilai pendidikan karakter tersebut terdiri dari karakter yang rendah hati, percaya diri, bekerja keras, hormat, dan santun.

\section{DAFTAR PUSTAKA}

Afdalipah, R., Ummah, S. S., \& Prastyo, D. (2020). Peningkatan Keterampilan Berbicara dengan Metode Bercerita Pada Anak Usia Dini di Sekolah Alam Excelencia Pamekasan. Kiddo: Jurnal Pendidikan Islam Anak Usia Dini. Kiddo: Jurnal Pendidikan Islam Anak Usia Dini, $1(1)$.

Alwi,Hasan dkk. 2007. Kamus Besar Bahasa Indonesia. Jakarta: Balai Pustaka

Apriani, H. S. (2013). "Pengembangan Keterampilan Berbicara Melalui Teknik Reka Cerita Bergambar Pada Anak TKK". http://www.repository.upi.ed. Diakses 25 April 2018.

Febrianshari, D., Kusuma, V. C., Jayanti, N. D., Ekowati, D. W., Prasetya, M. Y., Widiyanti, W., \& Suwandayani, B. I. (2018). Analisis nilai-nilai pendidikan karakter dalam pembuatan Dompet Punch Zaman Now. Jurnal Pemikiran dan Pengembangan Sekolah Dasar (JP2SD), 6(1), 88-95.

Firdaus, Z. Z. (2012). Pengaruh unit produksi, pengalaman prakerin dan dukungan keluarga terhadap kesiapan kerja siswa SMK. Jurnal pendidikan vokasi, 2(3).

Hasan. dkk. 2010. Penguatan Metodologi Pembelajaran Berdasarkan Nilai-nilai Budaya Untuk Membentuk Daya Saing dan Karakter Bangsa. Kemendiknas. Jakarta.

Hasibuan, N. S. (2019, September). ANALISIS NILAI MORAL DALAM CERITA RAKYAT SAMPURAGA PADA MASYARAKAT MANDAILING NATAL. In PROSIDING SEMINAR NASIONAL HASIL PENELITIAN (Vol. 2, No. 2, pp. 1184-1191).

Hasibuan, N. S., Puansyah, I., \& Hasibuan, A. Y. (2020). Analisis Cerita Rakyat Mandailing "Sampuraga": Suatu Kajian Pendekatan Objektif dan Nilai Pendidikan Karakter. Anthropos: Jurnal Antropologi Sosial dan Budaya (Journal of Social and Cultural Anthropology), 5(2), 222-235.

Hidayati, A. (2018). Peningkatan Keterampilan Berbicara Melalui Pendekatan Komunikatif Kelas V Sd Padurenan Ii Di Bekasi Tahun Pelajaran 2016/2017. Jurnal Ilmiah Pendidikan Dasar, 5(2), 83-95.

Kemendiknas. (2010). "Pembinaan Pendidikan Karakter di Sekolah Menengah Pertama". Jakarta:Badan Penelitian dan Pengembangan.

Kesuma, Dharma. dkk. 2012. Pendidikan Karakter Kajian Teori dan Praktik di Sekolah. Bandung: Remaja Rosdakarya. 


\section{JESYA}

JURNAL EKONOMI \& EKONOMI SYARIAH

Jurnal Ekonomi \& Ekonomi Syariah Vol 5 No 1, Januari 2022

E-ISSN : 2599-3410 | P-ISSN : 2614-3259

DOI : https://doi.org/10.36778/jesya.v5i1.681

Ningsih, S. (2014). Peningkatan Keterampilan Berbicara Melalui Metode Bercerita Siswa Kelas III SD Negeri 1 Beringin Jaya Kecamatan Bumi Raya Kabupaten Morowali. Jurnal Kreatif Online, 2(4).

Nurgiyantoro, B. (2001). Penilaian dalam Pengajaran Bahasa dan Sastra Edisi ke-3. Yogyakarta: PT BPFE.

Permendiknas (2006). Peraturan Menteri Pendidikan Nasional No. 23 Tahun 2006 tentang Tujuan Pendidikan.

Purwadi, A. J., Yulistio, D., \& Kurniawan, R. (2021). Peningkatan Keterampilan Berbicara Mahasiswa melalui Praktik Berpidato dan Praktik Bercerita Menggunakan Video Pembelajaran Praktik Berbicara. Silampari Bisa: Jurnal Penelitian Pendidikan Bahasa Indonesia, Daerah, Dan Asing, 4(2), 373-397.

Rahayu, R. (2016). Peningkatan karakter tanggung jawab siswa SD melalui penilaian produk pada pembelajaran mind mapping. Jurnal Konseling Gusjigang, 2(1).

Rofiecudin, A. dan Zuchdi, D. (2001). Pendidikan Bahasa dan Sastra Indonesia Kelas Tinggi. Malang: Universitas Negeri Malang.

Samani, Muchlas., \& Hariyanto. (2013). Pendidikan karakter, konsep dan model. Bandung: Remaja Rosdakarya.

Wahyudin, A. (2009). Analisis Hubungan Motivasi, Good Governance Terhadap Kinerja Institusi Pendidikan Yang Dimoderasi Karaktersitik Biografi. Jurnal Dinamika Akuntansi, 1(1).

Winkel, W. S. (2021). Bimbingan dan konseling di institusi pendidikan. 